\section{ECONOMICS}

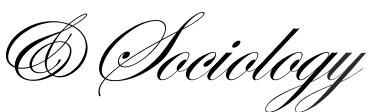

\author{
Bożena Karwat-Woźniak \\ Institute of Agricultural and Food \\ Economics \\ National Research Institute \\ (LAFE-NRI) \\ ul. Swietokrzyska 20, 00-002 \\ $W$ arszawa, Poland \\ k.arwat@ierigz.waw.pl,
}

Received: January, 2009

1st Revision: February, 2009

Accepted: March, 2009
Bożena Karwat-Woźniak, The Area of Cultivated Land as a Factor Determining Economic Potential of Private Farms, Economics \& Sociology, Vol. 2, No 1, 2009, pp. 47-57.

\title{
THE AREA OF CULTIVATED LAND AS A FACTOR DETERMINING ECONOMIC POTENTIAL OF PRIVATE FARMS
}

\begin{abstract}
Because of the acreage fragmentation and little economic power within most of the farms, the Polish agriculture in its general form is not prepared to effectively function under conditions of increasing liberalisation. The Improvement of competitiveness combines more intensified tendency towards increasing scale of production and the amount of economically strong farms. Under the conditions of Polish agriculture these processes combine land concentration, since such trends show pro-effective transformations within the agriculture sector. In respect of this, there has been done an analysis and assessment of the impact of agricultural lands on economical power of individual farms. The paper is mainly based on the results of long-term field research of IAFE-NRI (Institute of Agricultural and Food Economics - National Research Institute) carried out within all individual farms situated in certain 76 villages. The survey data was completed with the CSO (Central Statistical Office) materials. It has been stated that although, in general, together with an agricultural progress the land factor is losing its significance, from the point of view of an individual farm in Poland, the utilised agricultural land area determines its economic power. This was mainly indicated by the relations between farm's acreage and economic value, scale of sales and investment activity as well as farm income level. It has been assumed that 1 ha increase in the area of a farm gives $3-4 \%$ probability that the farm will switch to a higher production level ceteris paribus and as a result its economic power will increase
\end{abstract}

JEL Classification: Q12, Q15, D63

Keywords: Farm, economic power (potential), economic value, farm area, commodity production, investment enterprises

\section{Introduction}

The basic property and at the same time main requirement of the modern economy is market competition, while growing reduction of barriers, which restrain confrontation of economic entities, provokes increased competition, which also applies to farms. The process 
of globalization and the Polish membership of the EU is accompanied by a wide debate concerning competitiveness and condition of Polish agriculture sector, which in respect of its structural conditions barely adapted to effective functioning that is based on the market mechanisms [Woś 2000a].

In the present economic conditions, improvement of Polish agriculture sector competitiveness and increasing farmers' income became key issues. It has been accepted that the present structure of this economic activity segment requires actions towards land concentration and commodities production [Zegar 2008]. The necessity of the production scale growth of individual subjects is crucial and market mechanisms stimulate such trends [Zegar 1991]. Whereas, increased sale is generally accompanied by the growth of farms' economic power [Zegar 2003]. But the economic power of most Polish farms is still too small [Zegar 2003] and it does not give much opportunity to improve the ability to compete and to make more profits from agricultural activity. Such an attitude, in respect of the of Polish agriculture development level as well as high level of its area fragmentation, determines the need to increase a tendency to concentrate agricultural land [Frohberg 2000], which is a factor of specific kind of production [Woś 1998b]. In fact, together with the economic development, agricultural land loses significance within farm production increase, nevertheless, they have always been the basic and constant factor of farm minerals production. [Woś 1996].

Agricultural land is the most often mentioned element in indicating values and relations of economy and production in within individual farms [Kowalski 1998]. Although, the modern and common know-how methods decreased the significance and influence of the agricultural land acreage size in shaping production and economic effects of individual farms [Woś 2000b]. Still, under the conditions of Polish agriculture, in which in spite of improvement, the traditional productive model constantly prevails and the area structure of farms invariably indicates production abilities and further development of this sphere of national economy [Rudnicki 2005]. Despite the increase of productive potential of small area units may occur by way of production intensification, the capital restrictions and farmers' qualification level remain a barrier [Woś 1998a]. More than that, after the maximum threshold of production intensification is reached, sustaining a market position and further farm production increase will require enlargement of agricultural land acreage.

In respect of this, there is a point in making an analysis and assessment of the agricultural land in shaping economical power of individual farms and opportunities of its further increase.

The basic empirical material was based on a long-term field research carried out by IAFE-NRI in: 1996, 2000 and 2005. The survey covered all farms with agricultural land above 1 ha that were in ownership of natural persons ${ }^{1}$ in certain 76 villages of various country regions. The villages were picked in such a way that the area of the investigated subjects ${ }^{2}$ was proportional to the exact area structure of the general individual farms above 1 ha of agricultural land in Poland. The units covered in the survey accounted for ca. $0.2 \%$ of a total number of farms and their size in the last research i.e. 2005 accounted for 3705 units.

The statistical material from field research was completed with published and not published data of Central Statistical Office (GUS) concerning individual farms. The materials were acquired from The National Agriculture Census 2002 as well as from the empirical research carried in: 2005 and 2007 out on representative sample of ca. 200 thousand farms.

Long-term observation and huge amount of sample subject as well as using the same researching method, which conditioned the preservation of continuity and comparability of

\footnotetext{
${ }^{1}$ Natural persons' farms are in its essence individual farms.

${ }^{2}$ In this document the names: farm, unit, and subject are used interchangeably.
} 
data, made it possible to carry out reliable and complex analysis of relation between the area of agricultural land and economic power of a farm

In this document the financial categories are represented in current values. Such an attitude was conditioned with the nature of available empirical data and lack of possibilities of its presentation in comparable values ${ }^{3}$.

\section{Farms' economic power - definition, factors indicating it and determination methods}

Economic potential, also known as economic power, can be defined as capability resource of individual economic entities, because of which they can stay in the market. It also describes abilities of particularly efficient functioning in certain field that can occur within specific conditions or under influence of a specific factor (Pens 1997). Thus, it not only fixes the present condition of a specific unit, but also creates its further capabilities. For this reason the economic power is a dynamic category from both micro and macro perspective.

When farms are concerned, economic power indicates the farmer's ability to independently multiply resources and development of the used subject, its adaptation to changeable functioning conditions and ability to stay in the market (Woś 2000b). Consequently, economic power determines competition ability (to compete) of a specific farm $^{4}$.

Such specified economic power is not only determined by material elements of production resources or the position towards market and supply market, but also difficult to quantify factors such as skills and individual features of people engaged in a specific enterprise, in particular, people who hold leading and decisive functions (marketing and management skills, tendency to take a risk, perceptiveness, fast decision making, being communicative etc.). Such elements, in particular when individual farms are concerned, should also be extended by family condition of the user (Woś 2000). Thus, economic potential is a changeable category and, as a result, difficult to be clearly identified from individual farm as well as whole agriculture sector point of view.

All of the above mentioned conditions cause the economic power to be a very complex and difficult to describe (measure) value, as it is appointed by a number of graduated parameters, of which some are difficult to measure or cannot be measured at all. Thus, examination of individual farms' power has some features of deduction on the basis of general economic condition of individual groups of agriculture subjects (Woś 2000b).

For the purpose of empiric analysis of this paper the economic power of farms was measured with farm article sales scale, investment activity ${ }^{5}$ and agricultural income value as well as with economic value.

\section{The agricultural production sale index}

The knowledge concerning farms' economic potential and its relations towards area of agricultural land is acquired from information concerning the size of commodities production obtained in units of various acreages, especially that under conditions of increasing

\footnotetext{
${ }^{3}$ Commodity production and investment expenditures values were only available in value representation and lack of data concerning material structure of agriculture commodities sell as well as materials and investment services made it impossible to convert those values to fixed prices. Because of this the commodity production and investment expenditures values were in this entire study represented in nominal values.

${ }^{4}$ Competition ability (to compete) is an economic entities's skill to achieve, and later on preserve as well as enlarge a share on the market whos user they are [Kulawiak 2007]. In case of individual farms it is accepted that those subjects are able to compete, which achieve relatively high level (at least on a parity level) of farmers' works of one's own fee [Józwiak, Mirkowska 2007].

${ }^{5}$ Measured with the percentage of investing farms and the value of investment expenditures
} 
competition the position of farms within changeable environment is more often indicated by the amount of production that was sold by the user of individual units [Sikorska 2001]. At the same time the commodities production value is a peculiar "test" of specific farms" production capabilities and its graduated level shows disproportion in economic condition and value sizes, which farmers can use for restructuring programme and their workshops modernisation.

The empirical data analysis proofs that scale of agriculture production of individual units is very much indicated by the area of agricultural land. Those conditions are shown by the size of correlation coefficient between values of agriculture commodities sale and farms' acreage, which investigated group size was positive and which was included in range from 0.6464 in 1996 to 0.7114 in 2005 . Every time the described conditionality was therefore meaningful and raising value of correlation efficient showed not only relatively big, unilateral and positive correlation of sale value with farm acreage ${ }^{6}$ but also its accumulation.

Table 1. The value of commodities production according to area of farms (current prices)

\begin{tabular}{|c|c|c|c|c|c|c|}
\hline \multirow{4}{*}{ Specification } & \multicolumn{6}{|c|}{ An average value of agriculture production sale } \\
\hline & \multicolumn{2}{|c|}{1996} & \multicolumn{2}{|c|}{2000} & \multicolumn{2}{|c|}{2005} \\
\hline & \multicolumn{6}{|c|}{ PLN thousand per } \\
\hline & 1 farm & $\begin{array}{c}1 \text { ha of } \\
\text { agricultur } \\
\text { al land }\end{array}$ & 1 farm & $\begin{array}{l}1 \text { ha of } \\
\text { agricultur } \\
\text { al land }\end{array}$ & 1 farm & $\begin{array}{l}1 \text { ha of } \\
\text { agricultur } \\
\text { al land }\end{array}$ \\
\hline Total & 18.2 & 2.2 & 25.1 & 2.7 & 36.5 & 3.5 \\
\hline \multicolumn{7}{|c|}{ Farm area groups (ha per agricultural land) } \\
\hline $1-5$ & 6.9 & 2.6 & 8.9 & 3.3 & 9.7 & 3.6 \\
\hline $5-10$ & 16.7 & 2.4 & 20.7 & 3.0 & 23.1 & 3.3 \\
\hline $10-15$ & 26.1 & 2.2 & 31.2 & 2.6 & 38.5 & 3.3 \\
\hline $15-20$ & 37.8 & 2.0 & 41.2 & 2.4 & 60.5 & 3.6 \\
\hline $20-30$ & 55.0 & 2.0 & 69.0 & 2.9 & 87.6 & 3.7 \\
\hline $30-50$ & 84.5 & 1.8 & 100.6 & 2.7 & 136.3 & 3.6 \\
\hline 50 and more & 150.5 & 1.6 & 207.4 & 2.2 & 387.1 & 4.0 \\
\hline \multicolumn{7}{|c|}{ Relation of sell index of 50 hectare and more farms to: } \\
\hline $1-5$ ha farms & 2181 & 62 & 2330 & 67 & 3991 & 111 \\
\hline all of the investigated & 827 & 73 & 826 & 81 & 1061 & 114 \\
\hline
\end{tabular}

Source: Prepared on the basis of IAFE survey for 1992, 1996, 2000 and 2005

The regularity, which indicates a distinct relation between sales volume and area of the farm, not only marked itself in the whole period from 1996 to 2005, but strengthen in general. It is so not only because of the correlation efficient forming between commodities production value and farm acreage but also the growing spread of sell volume achieved in group of farms from 1 to 5 ha as well as 50 ha units and bigger (table 1). In 1996 the relation between the average sell value within the smallest and largest farms was like 1 to 22, whereas in 2005 analogical indicator was like 1 to 40 .

It should be as well marked that farms relatively large in area were using the land factor more efficiently. Such tendencies were for example showed by the growth of agricultural land productivity, measured by agricultural production sell volume of area unit. The scale of changes in such scope is showed by the change of commodity production value

\footnotetext{
${ }^{6}$ The correlation efficient is situated within -1 to 1 range, whereas, the more its value strays from 0 the stronger relation between the variables is and the sign describes the nature of this relation [Szulc 1969].
} 
of 1 agricultural land achieved by farms of larger areas in relation to both all of the investigated and the smallest area units from 1996 to 2005. In 1996 the volume of agricultural products sell from unit area within 50 ha and larger farms amounted to $62 \%$ of commodity production value achieved within units from 1 to 5 agricultural land and $72 \%$ within overall of investigated. In 2005 analogical indices determined 111 and 114\%.

The arguments that agricultural land is unchangeably conditioned by the scale of ongoing agricultural enterprises are also confirmed by the analysis of farm acreage according to the main goal of conducted agricultural enterprise (chart 1). For example, an average area of agricultural lands within the group of units with production exclusively for own purposes in 2005 accounted for 2.7 ha and was above five times smaller than the acreage of subject producing mainly for the market ${ }^{7}$, which accounted for 14.0 ha of agricultural land. Five years before, the average area of farm, which production was mainly for selling purposes, was almost one fifth smaller and accounted for 11.1 ha of agricultural land.

Figure 1. The average area of individual farms according to their market activity

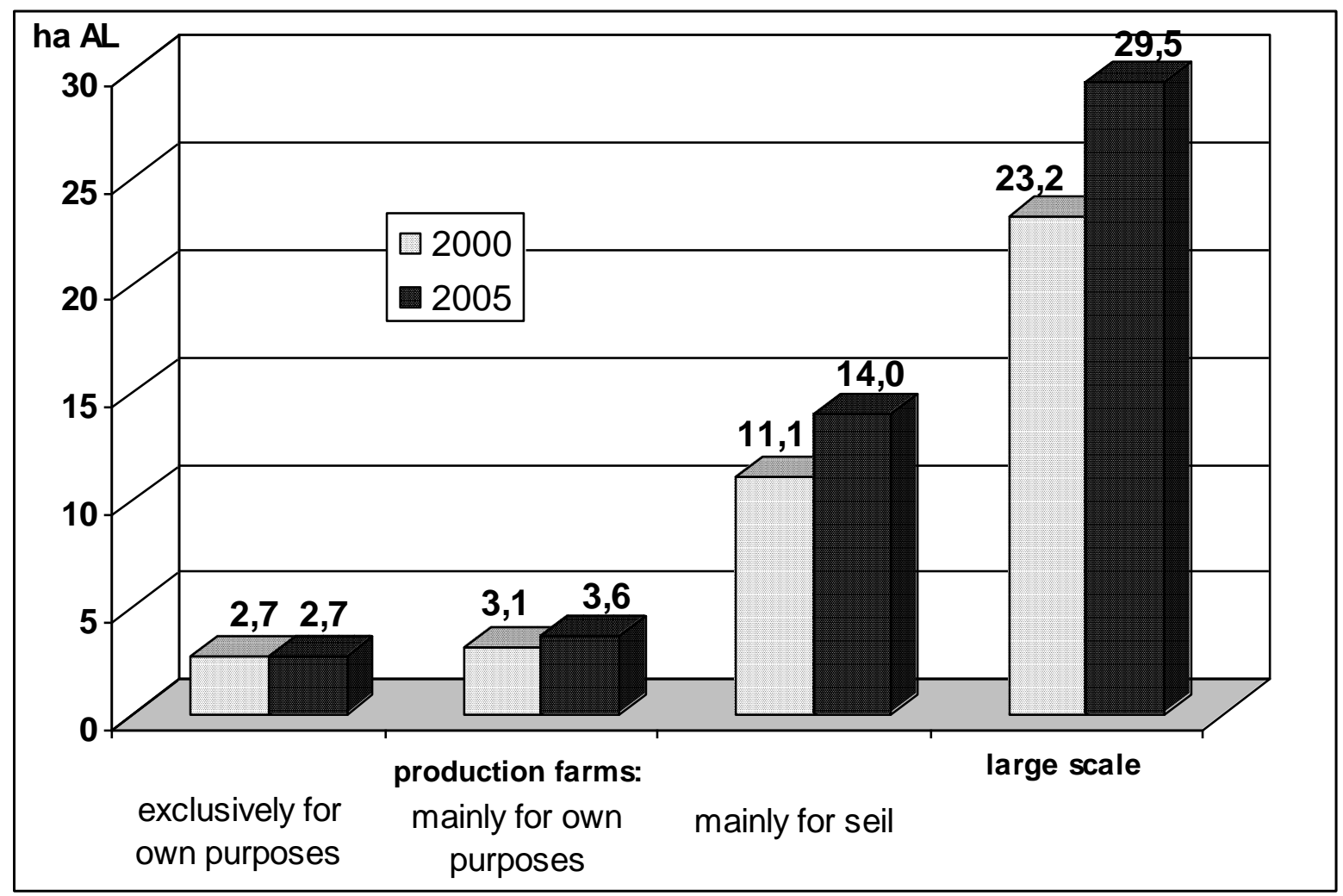

Source: Prepared on the basis of IAFE-NRI 2000 and 2005 survey data.

Nevertheless, the possession of production scale that allows achieving the income from work in farm that would be equal to average earnings from beyond agriculture activity required farming on a bigger acreage of agricultural land. In 2005 the average acreage of agricultural land in a group of units that fulfilled this requirement accounted for 29.5 ha of agricultural land. Within the research conducted in IAFE-NRI the subjects of which the size of agricultural commodities production provided opportunities to achieve such an income, were called large scale production farms [KarwatWoźniak 2005, 2007].

\footnotetext{
7 The farms acccepted as those, which produced mainly for the market (for sell) must have had PLN 5 thousand of sell in 2000 and PLN 7 thousand in 2005.
} 
It should be also mentioned that relatively large farms are dealing better within the conditions of economic agricultural downturn. According to the Research Institute for Economic Development of Warsaw School of Economics research, the farms of at least 50 ha of agricultural land are dealing relatively best within the economic downturn.

\section{Investing}

The other factor that allows to make conclusions about farms economical potential is investing activity ${ }^{8}$. An enterprise maintained within a particular subject to restore, enlarge and modernisation of production assets proves that good results are achieved from agricultural enterprises because it accumulates funds for investments, which as a result enlarge its production potential in the future and as a consequence the economic power growth.

The investment enterprise also shows that farmers are unceasingly inclined and skilful enough to adapt to changing environment. Successful adaptation is a condition to maintain farms competitiveness mainly when long period of time is concerned [Józwiak, Mirkowska 2007].

Figure 2. The share of farms with agriculture investments

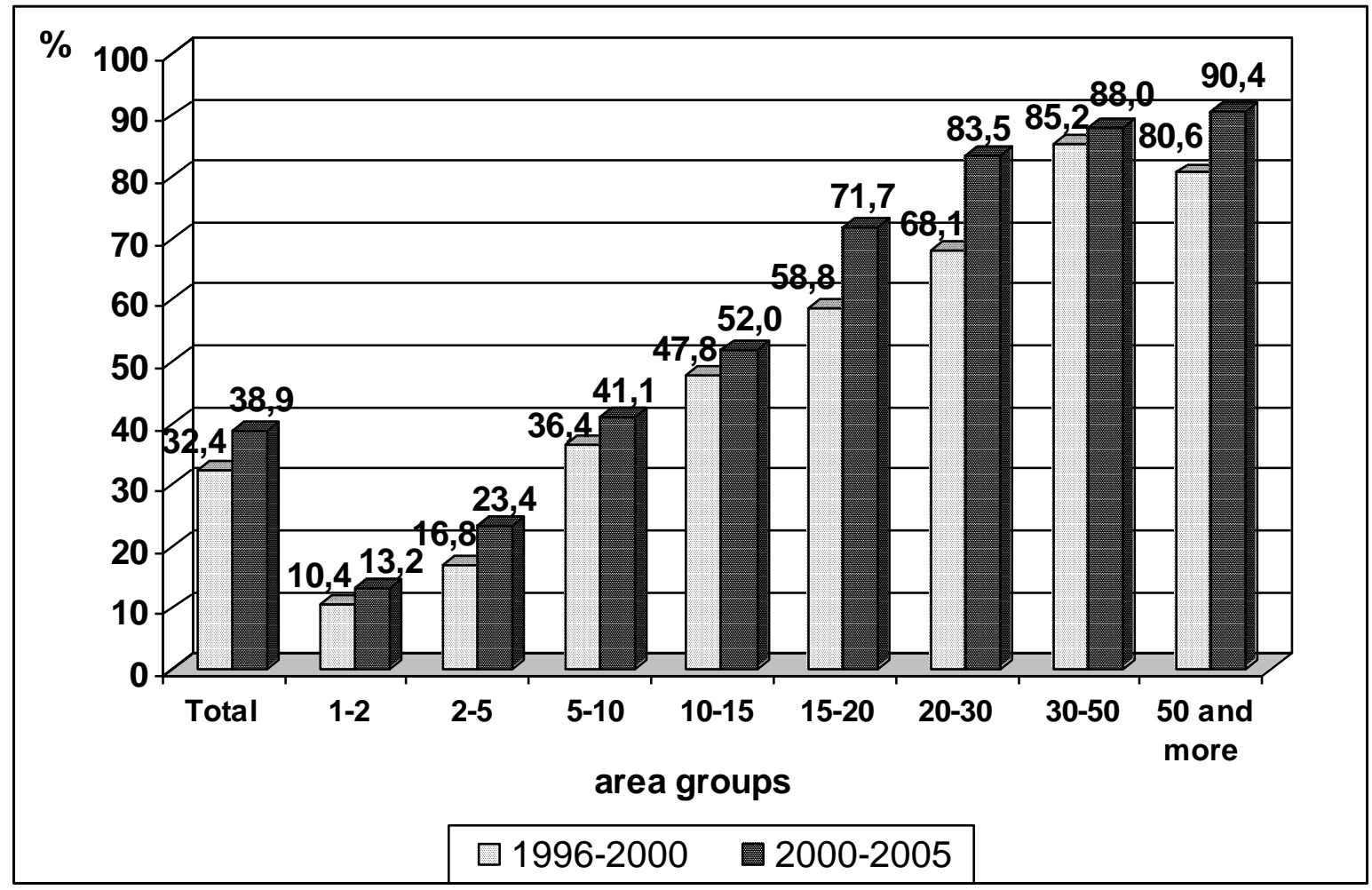

Source: Prepared on the basis of IAFE-NRI 2000 and 2005 survey data.

The analysis of general activity to restore, enlarge and modernise fixed assets of individual production farms and of the frequency of maintaining particular investments directly connected with agricultural enterprise revealed vast disproportion in this scope, between farms that have small, average or large acreage of agricultural land (figure 2 and table 2.).

The survey have shown that from 2000 to 2005 the percentage of units with production investments increased from $13 \%$ within the group of the smallest farms ( 1 to 2 ha

\footnotetext{
${ }^{8}$ Measured with the percentage of investing farms and the value of investment expenditures.
} 
of agricultural land) to as much as $90 \%$ of the largest farms (50 ha and more), which shows that the difference in the occurrence of investment enterprise within the smallest farms was almost seven times smaller than within the largest farms. More than that, together with the growth of a farm, the number of implemented investment enterprises increased (on average from 1.1 activity within 1 to 2 ha agricultural land area to 2.4 activities within the group of the largest units).

Because of that, disproportions between investment activities of farms ranging 1 to 2 ha of agricultural land, and those that have 50 ha and more in accordance to individual investment directions were much bigger. In case of expenditures for:

- construction, modernisation and renovation of utility buildings - almost ten times $(6 \%$ in view of $58 \%$ ),

- purchase of a basic herd of a livestock - also ten times (4\% in view of 39\%),

- restoration, enlargement and modernisation of machinery stock - somewhat twenty four times $(3 \%$ in view of $73 \%)$,

- soil purchase - twenty four times ( $2 \%$ in view of $52 \%$ ).

The value of money input assigned for production investments indicated even stronger connection with farms' areas than frequency of enterprises within restoration, enlargement and modernisation of fixed production assets. Such dependency was visible regardless of the time of research. In 1992-2005 size of correlation efficiency between the area of a farm and agriculture investments expenditure accounted for ca. 0.6287 .

Table 2. Production Investments of farms according to their size in 2000-2005

\begin{tabular}{|c|c|c|c|c|c|c|}
\hline \multirow{3}{*}{$\begin{array}{l}\text { Area groups } \\
\text { (ha AL) }\end{array}$} & \multicolumn{5}{|c|}{ The share of farms investing in fixed production assets } & \multirow{3}{*}{$\begin{array}{c}\text { Average } \\
\text { expenditure cost } \\
\text { (in PLN } \\
\text { thousands per } 1 \\
\text { farm) }\end{array}$} \\
\hline & \multirow[b]{2}{*}{ total } & \multicolumn{4}{|c|}{ including } & \\
\hline & & buildings & machinery & flock & soil & \\
\hline total & 38.9 & 21.8 & 19.8 & 10.2 & 8.3 & 41.9 \\
\hline $1-2$ & 13.2 & 5.8 & 3.1 & 3.6 & 2.4 & 11.6 \\
\hline $2-5$ & 23.4 & 12.2 & 7.0 & 4.2 & 4.9 & 12.5 \\
\hline $5-10$ & 41.1 & 22.0 & 18.2 & 8.3 & 5.7 & 13.8 \\
\hline $10-15$ & 52.0 & 31.2 & 33.0 & 12.1 & 7.0 & 29.7 \\
\hline $15-20$ & 71.7 & 41.2 & 40.9 & 20.1 & 15.8 & 31.0 \\
\hline $20-30$ & 83.5 & 45.5 & 53.5 & 33.0 & 25.0 & 56.8 \\
\hline $30-50$ & 88.0 & 63.9 & 65.7 & 36.1 & 35.2 & 103.0 \\
\hline 50 and more & 90.4 & 57.7 & 73.1 & 38.5 & 51.9 & 402.4 \\
\hline
\end{tabular}

Source: Prepared on the basis of IAFE-NRI 2005 survey data.

The average expenditures covered within 5 year period: 2000-2005 by investing farms from extreme size groups differed almost thirty five times (11.6 and 402.4 thousand per 1 farm). It should be at the same time pointed out that this differences were much lower within previous periods of time. The maximum span of average expenditures for production investments in extreme area groups was: in 1992-1996 - twenty four times (PLN 3.5 and 95.3 thousand) in 4 year period 1996-200 - thirty times (PLN 6.6 and 219.6 thousand per 1 farm).

\section{Relation between economical value and area of a farm}

In respect of farms, the most multiple meter, which allows to considerably synthetic describe the economic power of individual units is economic value. Thus, it not only 
considers the scope of agricultural enterprise but also a relatively wide spectrum of production and cost parameters as well as local conditions of functioning of farms [Jóźwiak, Mirkowska 2004].

The Economic value is a total amount of standard gross margins of all farm activities maintained within a specific farm.

Standard Gross Margin is measured in Euro. It is a difference between the value of achieved production within a particular farm enterprise and margin costs of its manufacture. In order to limit periodic changes within production conditions, average value of three consecutive years is being calculated. The value of production and its manufacture margin costs. The SGM is being fixed for each type of a crop and specie and production and functional groups of livestock in a specific time and region ${ }^{9}$ of the country. While describing SGM, the local diversity under which farms function i.e. prices, crops, livestock productivity, manufacture technology etc. are considered.

The economic value is presented in European Size Unit (ESU). 1 ESU is from 1984 worth EUR 1200

Figure 3. The average size of agricultural land within individual groups of individual farms' economic value in consecutive years of research

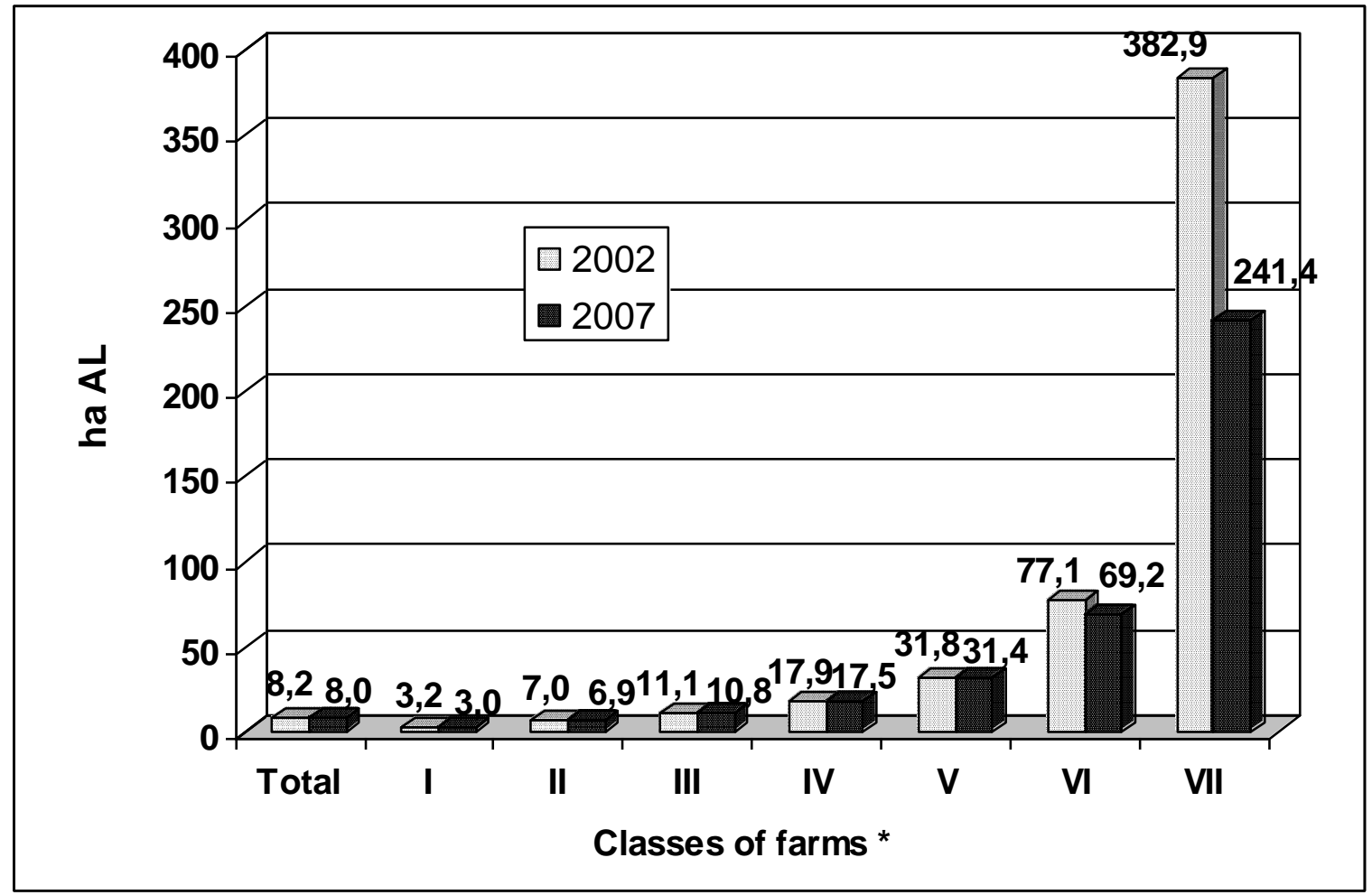

*The following designates were used of individual classes of farms' economical value I - up to 2 ESU; II - 2 to 4 ESU; III - 4 to 8 ESU; IV - 8 to 16 ESU; V - 16 to 40 ESU; VI - 40 to 100 ESU; VII - 100 and more ESU.

Source: prepared on the basis of unpublished Central Statistical Office data.

The statistical individual farm of more than 1 ha of agricultural land, which maintained agricultural enterprise in 2007 possessed 8.0 ha of agricultural land and its economical value accounted for $4.4 \mathrm{ESU}^{10}$, whereas those factors were connected with each other (chart 2). The average area of farm in 2007 increased from 3,0 of agricultural land in

\footnotetext{
${ }^{9}$ Voivodeships in case of Poland.

${ }^{10}$ For comparison, the average economic value of an European Union farm accounted for 10.5 ESU in 2005.
} 
class to 2 ESU (in 20023.2 ha of agricultural land.) to ca. 241.4 ha of agricultural land, in class 100 and more ESU (in 2002 - 382.9 ha of agricultural land).

It means that the span of usual agricultural land acreage, which is cultivated by the farms of the biggest and smallest economic value between 2002 and 2007 reduced around $40 \%$. Thus, it was still relatively big as in 2005 the usual area of class 100 and more ESU farms was almost eighty times bigger comparing to analogical indicator of 2 ESU units.

The arguments for dependency between area of a farm and its economical value is also supported by farms' structure in accordance with their area and economic power (Table 3 ).

Table 3. Individual agricultural farms structure according to acreage and economic size in subsequent years of research.

\begin{tabular}{|c|c|c|c|c|c|c|c|c|}
\hline \multirow{4}{*}{$\begin{array}{c}\text { Acreage } \\
\text { groups } \\
\text { (in ha) }\end{array}$} & \multirow{4}{*}{ Year } & \multicolumn{7}{|c|}{ Economic size classes } \\
\hline & & to 2 & $2-4$ & $4-8$ & $8-16$ & $16-40$ & $40-100$ & 100 and more \\
\hline & & \multicolumn{7}{|c|}{ in ESU } \\
\hline & & \multicolumn{7}{|c|}{ total $=100$} \\
\hline \multirow{3}{*}{ Total } & 2002 & 55.1 & 17.2 & 14.6 & 8.9 & 3.6 & 0.5 & 0.1 \\
\hline & 2005 & 56.6 & 16.8 & 13.1 & 8.5 & 4.2 & 0.7 & 0.1 \\
\hline & 2007 & 56.7 & 17.0 & 12.6 & 8.3 & 4.5 & 0.8 & 0.1 \\
\hline \multirow{3}{*}{$1-2$} & 2002 & 96.1 & 2.2 & 0.8 & 0.5 & 0.3 & 0.1 & - \\
\hline & 2005 & 96.4 & 2.0 & 0.7 & 0.6 & 0.2 & 0.1 & $(\cdot)$ \\
\hline & 2007 & 96.5 & 1.8 & 0.7 & 0.5 & 0.4 & 0.1 & $(\cdot)$ \\
\hline \multirow{3}{*}{$2-5$} & 2002 & 80.2 & 15.9 & 2.9 & 0.6 & 0.3 & 0.1 & $(\cdot)$ \\
\hline & 2005 & 79.3 & 16.2 & 3.4 & 0.6 & 0.4 & 0.1 & $(\cdot)$ \\
\hline & 2007 & 81.1 & 15.1 & 2.7 & 0.7 & 0.3 & 0.1 & $(\cdot)$ \\
\hline \multirow{3}{*}{$5-10$} & 2002 & 32.4 & 37.2 & 25.2 & 4.4 & 0.7 & 0.1 & $(\cdot)$ \\
\hline & 2005 & 31.1 & 36.7 & 25.6 & 5.4 & 0.9 & 0.2 & $(\cdot)$ \\
\hline & 2007 & 31.1 & 38.4 & 24.6 & 4.8 & 0.9 & 0.2 & $(\cdot)$ \\
\hline \multirow{3}{*}{$10-15$} & 2002 & 8.4 & 19.7 & 44.7 & 23.7 & 3.2 & 0.3 & $(\cdot)$ \\
\hline & 2005 & 6.1 & 22.8 & 40.7 & 26.1 & 3.9 & 0.3 & 0.1 \\
\hline & 2007 & 4.1 & 24.3 & 40.8 & 26.2 & 4.2 & 0.4 & $(\cdot)$ \\
\hline \multirow{3}{*}{$15-20$} & 2002 & 3.5 & 8.5 & 32.9 & 44.1 & 10.4 & 0.5 & 0.1 \\
\hline & 2005 & 2.2 & 8.6 & 30.3 & 44.3 & 13.8 & 0.7 & 0.1 \\
\hline & 2007 & 1.4 & 8.9 & 29.1 & 45.3 & 14.4 & 0.8 & 0.1 \\
\hline \multirow{3}{*}{$20-30$} & 2002 & 1.9 & 3.6 & 18.2 & 49.2 & 25.7 & 1.3 & 0.1 \\
\hline & 2005 & 1.4 & 2.7 & 17.4 & 45.4 & 31.0 & 1.9 & 0.2 \\
\hline & 2007 & 1.1 & 2.0 & 17.8 & 43.7 & 33.3 & 1.9 & 0.2 \\
\hline \multirow{3}{*}{$30-50$} & 2002 & 1.4 & 1.4 & 7.3 & 35.3 & 49.0 & 5.2 & 0.4 \\
\hline & 2005 & 0.7 & 0.9 & 5.7 & 30.8 & 53.7 & 7.7 & 0.5 \\
\hline & 2007 & 0.2 & 0.4 & 4.9 & 30.0 & 56.4 & 7.7 & 0.4 \\
\hline \multirow{3}{*}{50 and more } & 2002 & 1.2 & 0.8 & 2.1 & 13.2 & 50.1 & 23.6 & 9.0 \\
\hline & 2005 & 0.4 & 0.7 & 1.5 & 10.6 & 49.7 & 29.8 & 7.3 \\
\hline & 2007 & 0.2 & 0.1 & 0.8 & 9.2 & 50.7 & 30.9 & 8.1 \\
\hline
\end{tabular}

Source: Author's calculations on data of Central Statistical Office (GUS) 2002, 2005 and 2007.

The analysis of farm distribution according to their economic size in particular acreage groups documented that this relation is not linear and that units with the same acreage may possess a different potential; entities with a small economic size were mainly among units small in terms of acreage, whereas stronger farms were usually of bigger acreage

Both, in 2002 and in 2007 in the group of the smallest farms (from 1 to 2 ha) more than $96 \%$ of units possessed an economic power lower than 2 ESU, and the potential of other $2 \%$ was between 2 and 4 ESU. A value above 4 ESU, i.e. above the average for all individual 
farms, was achieved only by about $2 \%$ of farms with such a small acreage, while farms of more than $40 \mathrm{ESU}$ power were almost not present.

On the other hand, farms bigger in size are usually of significant economic power. If 16 ESU is recognised as a high economic value, in all analysed years, subjects with such power occurred occasionally in the acreage group from 1 to 2 ha and consisted $0.3-0.4 \%$ of farms with this small acreage. Whereas among farms of 50 ha and larger, values above 16 ESU prevailed and their percentage in 2002 was about 80\%, 87\% in 2005 and almost 90\% in 2007.

\section{Conclusions and employment transformations forecast in individual farming}

On the basis of conducted analyses and available empirical data. it can be stated that the presented material provides evidence that there is not only a connection between an economic potential and an area of agricultural lands cultivated by particular farms but also in case of Polish agriculture this relation was reinforced by growing competitiveness. Admittedly, this connection does not have a linear character but a positive and significant influence of farm acreages was emphasised in an economic size, amount of market production as well as in investment activity and the amount of resources assigned for financing activities aiming at reconstruction, innovation and modernisation of tangible assets (correlation coefficients were included in a range from 0.6287 to 0.7654 ). However, the value of correlation coefficient, the structural distribution of farms according to their acreage as well as their economic power irrespective of an indicator illustrating it show that acreage is still a factor of great importance for potentials of particular subjects.

Processes of economic power growth in agricultural holdings are stimulated by a number of factors an influence of which is indicated to a large extend by external functioning conditions. However, irrespective of general economic conditions, agricultural lands played always a favourable role in evolution of subjects producing agricultural raw materials. Cultivation land increase of 1 ha of agricultural land enhanced the chance of improving commodity manufacturing scale by 3 to $4 \%$.

Remodelling of agricultural structures, especially in the scope of economic power growth of individual farms and in consequence the improvement of the whole Polish agriculture sector competitiveness are connected and will still be related to processes of agricultural lands concentration. These tendencies are being reinforced by globalisation processes whose influence is gradually stronger.

\section{References}

1. Frohberg K. (2000): Konkurencyjność polskiego rolnictwa [w:] Strategiczne opcje dla polskiego sektora agrobiznesu w świetle analiz ekonomicznych. SGGW. Warsaw. p 239

2. Józwiak W., Mirkowska Z. (2007): Ekonomiczne przesłanki zdolności konkurencyjnej polskich gospodarstw rolnych. [in:] Sytuacja ekonomiczna i aktywność inwestycyjna różnych grup gospodarstw rolniczych w Polsce i innych krajach unijnych w latach 2004-2005. Ed. W. Józwiak. IAFE-NRI. Warsaw, p 7.13.

3. Józwiak W., Mirkowska Z. (2004): Średnie. duże i bardzo duże gospodarstwa w Niemczech. Austrii Danii i Polsce w latach 1997-2001. Komunikaty. raporty. Ekspertyzy. vol. 499. IAFE. Warsaw. $\mathrm{p} 7$.

4. Kapusta F.. (2008): Agrobiznes. Difin, Warsaw, p. 97.

5. Kowalski A. (1998): Czynniki produkcji w agrobiznesie. [in:] Encyklopedia Agrobiznesu. Red. A. Woś. Fundacja Innowacja. Warsaw. p 109. 
6. Kulawik J. (2007): Efektywność a konkurencyjność. [in:] Analiza efektywności gospodarowania i funkcjonowania przedsiębiorstw rolnych powstałych na bazie majątku byłych PGR. Red. J. Kulawik. W. Józwiak. IAFE-NRI. Warsaw . p 27-31.

7. Pens J. (1997): Leksykon biznesu. Agencja Wydawnicza Placet. Warsaw. p 331.

8. Rudnicki H. (2005): Przemiany strukturalne w polskim rolnictwie w okresie transformacji systemowej. [in:] Kwestia agrarna w Polsce i na świecie. SGGW. Warsaw, p 184.

9. Woś A. (1998a): Agrobiznes. Makroekonomika. Vol. 1. Wydawnictwo Key Text. Warsaw, p 96.

10. Szulc B. (1969): Statystyka dla ekonomistów. Opis statystyczny. PWE, p 329.

11. Woś A. (2000a): Rolnictwo polskie 1945-2000. Porównawcza analiza systemowa. IERiGŻ. Warsaw, vol. 24 and following

12. Woś A. (2000b): Układy strukturalne w rolnictwie chłopskim (w świetle danych rachunkowości rolnej). Komunikaty. Raporty. Ekspertyzy. p. 465. IAFE, Warsaw, p. $9,12$.

13. Woś A. (1998a): Wzrost gospodarczy i strategie rozwoju polskiego rolnictwa. Eseje 2. IAFE. Warsaw. p 61.

14. Woś A. (1998b): Zasoby odnawialne w agrobiznesie. [in:] Encyklopedia Agrobiznesu. Ed. A. Woś. Fundacja Innowacja. Warsaw, p 951.

15. Zegar J. S. (2008): Dochody w rolnictwie w okresie transformacji i integracji europejskiej. IAFE-NRI. Warsaw, p 123-124.

16. Zegar J. S. (1991): Gospodarstwo i ludność chłopska współcześnie. IAFE, Warsaw, p 31.

17. Zegar J. S. (2003): Niektóre problemy rolnictwa w świetle spisów. [in:] Zróżnicowanie regionalne rolnictwa. Ed. J.S. Zegar. CSO 